\title{
A Comparitive Study on Politics in Sathyajith Ray’s Films-Appu Triology, Mahanagar, Jana Aranya, Charulatha and Pathirdwani
}

Ramis Salam P*

Department of Mass Communication and Journalism, Pazhassiraja Collge, Calicut University, Pulpally, Kerala, India

\begin{abstract}
The most celebrated eminent Indian film director Satyajit Ray pasteurised the political history of India during 70 's and 80 's through his films. It looks different and gets more popularity. Politics, the word itself does not a word which used for valance and protest, otherwise politics is the internal evolution of human beings. The Ray characters played a very important role in deliver the political circumstances in 70's and 80's. It may be a striking political lesson. Politics, the word most commonly used for convey the provoking idea to the people. Satyajit Ray tries to wipe out the evil face of politics through his films In this study politically analysis the films Appu Trilogy, Jana aranya, Charulatha and Prathidhwani with the help of Indian political scenarios. This study is based on the content analysis of Sathyajith ray movies. The study conducted based on the method of mise-en scene of Sathyajith ray films. The study is also based on the theoretical frame work of Gandhian aproches and Marxian view. This paper finds out that, Sathyajith ray films are highly political, with respect to the senario of those period of film are made.
\end{abstract}

Keywords: Political; Political cinema; Parallel cinema; A political tool; Propaganda

\section{Introduction}

The politics in the films of Satyajith Ray has not been much examined. There are many legends of Indian film making; Satyajith has yet not being recognised as a political film maker. Comparing with the film of Rithwik Ghatak and Mrinal Sen which are politically highly influential, Sathyajith Ray himself claims he is never a political film maker. But when we closely examine his films, we could read out a close relationship with Indian politics in his films [1]. He was an Indian Bengali filmmaker, wildly regarded as the one of the great filmmaker in 20th century. Ray was born in the city of Culcutta in to a Bengali family prominent in the world of arts and literature. Starting his career as a commercial artist, Ray was drown in to independent filmmaking after meeting French filmmaker Jean Renoir and viewing Vittorio De Sica's Italian neorealist film Bicycle Thieves [2]. During a visit to London, Ray directed 36 film including feature film documentaries and short. He was also fiction writer, publisher, illustrator, calligraphy, music composer, graphic designer and film critic. He authored several short stories and novels primarily. Aimed at fictional characters created by him, he was an honorary degree by Oxford University.

\section{Politics and Political Films}

A political film in the narrow sense of the term refers to cinema which portrays current or historical event or social conditions in a partisan way in order to inform or to agitate the spectator. Political cinema exists in different forms such as documentary, feature films, or even animated and experimental films. Political cinema in the narrow sense of the term refers to political films which do not hide their political stance. This does not mean that they are necessarily pure propaganda. The difference to other films is not that they are political.

Ideology and politics in cinema are often deliberately interconnected, but probably more frequently kept apart. Indeed, for many politically oriented film makers the purpose of their work is to show how intertwined ideology and politics happen to be in relation to individuals lives, and to show how many film makers have refuse to accept it. Film and politics entangled almost from the time of the first projections. As a promising new business, the movies become the subject of intense commercial struggles, while as an impassive new medium they were quickly perceived as a potential ideological influence.

\section{Indian Political Films}

Despite of the extremely strict censorship of the Cinema Board of Certification, Indian cinemas deal, whether overtly or covertly, with the political or social issues that the country faces. Actually, there are almost as many representations of politics on screen as there are Indian cinemas: nationalism and patriotism in Hindi films, regionalism in Tamil films or social and realistic cinema in Bengali films. After Independence, it was necessary to build a unified Indian nation not only for the politicians but also for the Hindi film industry, which sought to strengthen the nation around the values of Nehruvian socialism, as well as define Indianness through movies that reached out for the patriotic and nationalist sides of the public. By showcasing stereotypical characters representing an idealized society, Hindi films portrayed an ideal Indianness [3] Mother India by Mehbook Khan, 1957 and films like Kabhi Khushi Kabhi Gham [4] or, even more so Devdas, allow the family structure to be a metaphor for the nation, in which family conflicts are resolved as metaphors for national issues. Actually, observers tend to say that it has actually rather promoted a "Hindiness", with minorities generally overshadowed by the hero. This is particularly the case with religious minorities and the representation of Muslims in Hindi films.

\section{Review of Literature}

Political cinema in the narrow sense of the term refers to political

*Corresponding author: Salam PR, Assistant professor, Department of Mass Communication and Journalism, Pazhassiraja Collge, Calicut University, Pulpally, Kerala, India, Tel: 04936243 333; E-mail: ramissalam@gmail.com

Received September 06, 2016; Accepted September 26, 2016; Published September 29, 2016

Citation: Ramis Salam P (2016) A Comparitive Study on Politics in Sathyajith Ray's Films-Appu Triology, Mahanagar, Jana Aranya, Charulatha and Pathirdwani. J Mass Communicat Journalism 6: 316. doi: 10.4172/2165-7912.1000316

Copyright: $\odot 2016$ Ramis Salam P. This is an open-access article distributed unde the terms of the Creative Commons Attribution License, which permits unrestricted use, distribution, and reproduction in any medium, provided the original author and source are credited. 
films which do not hide their political stance. This does not mean that they are necessarily pure propaganda. The difference to other films is not that they are political but how they show it. Even ostensibly "apolitical" escapist films, which promise "mere entertainment" as an escape from everyday life, however, fulfil a political function. The authorities in Nazi Germany knew this very well and organized a large production of deliberately escapist movies. Guy Debord, a critic of the society of the spectacle, for whom "separation is the alpha and omega of the spectacle", was therefore also violently opposed to cinema, even though he would make several movies portraying his ideas.

\section{Indian Political Film}

Bengal renaissance is an awakening $18^{\text {th }}$ and $19^{\text {th }}$ century Bengal which influenced each and every aspect of Bengali life including cultural, social, religious and spiritual area [5]. During 1950s and 1960s Bengali cinema had to come out of the redundancy of independenceseeking, social films or mythologically oriented filmic fantasies [6]. Rabindranath Tagore's novella Nashtanir (The Broken Nest, 1901) was adapted by Satyajit Ray when he directed a film version of it with the title Charulata: The Lovely Wife in 1964 . He wrote the screenplay as well. Ray's film, like Tagore's Nashtanir upon which it is based, is set at the height ofthe Bengal Renaissance, about 1879 [7]. In Charulata as in Ghare Baire (The Home and the World, 1984), Satyajit Ray explores the emergence of the modern woman in the upper-class of colonial India. One cannot help drawing parallels with Ibsen's A Doll's House [8]. One can locate three major compositional periods in Ray's work and life. The first period (1955-1964) was remarkable for its robust optimism, celebration of the human spirit as well as a certain satisfaction and selfconfidence in assuming full auteurship [9].

Ray was not only directing and scripting, he was scoring the music and increasingly taking charge of the camera-work. During this period, he directed, arguably, his greatest films following a trajectory that can be traced back to his family background, his education in art, music and letters, and to the East-West cultural confluence that captured what one can call "Calcutta Modern". One must point out that this phase coincides with the first flush of independence in India or the idea of India that was being forged with yet to be tested forces of nationalism/ internationalism, secularism, humanism and modernism of the Nehru era (1947-64)

The films he made during this period clearly projected a troubled vision of India. The "Calcutta Trilogy" Partidwandi, Seemabaddha, Jana Aranya was a powerful portrait of alienation, waywardness and moral collapse among the urban youth [10]. Satyajith ray has always given equal screen space to men and women. He liberated women from the stereotyped Indian 'Sati- Savitri' who were obedient to men and he boldly pasteurized women as emotionally stable individual who resisted the patriarchal set up. While discussing Rays's women character, the most importance goes to Charulahta [11]. Satyajith Ray Mahanarar takes place in post independent India. The emergence of Calcutta in to a metropolitan city forced to take up jobs outside home. In Mahanagar, Arati, the protagonist decides to work because it is necessary for her to save her joint family from absolute poverty [10].

\section{Political Films in World Review}

Research in related social science fields has documented the negative effects of self-objectification on female mental health, sexuality, and attitudes and beliefs. This research examines the political effects of self-objectification and finds that it is negatively related to both internal and external political efficacy [12]. This study examined the values, attitudes, and beliefs depicted in American political films from 1968 to 1980. A historical analysis of eleven films was used to chart the changing landscape of an important transitional period in both American film and political history [13]. According to Harry Keyishian, motion pictures of the first period, from 1900 to the mid 1940 's, depicted a hero who could maintain both integrity and political power. Viewers who are "not prepared" to be critical about what they are seeing on screen were more likely to experience when watching Hollywood movies with an underiying liberal message. A team of political scientist at the Univesity of Notre Dame in Indiana set out of explore the power of political messages in popular films, and found that they possess the ability to change attitudes, especially on issues that are unframed by the media" [14]. Dr Todd Adkins the study's lead author wrote that: "Media effects research has generally ignored the possibity that popular film can affected political attitude" an omission which he describe as "puzzling".

An interview made by Cineaste magazine Ray answered the questions "Given the political climate in India, is the filmmaker's role one of passive observer or activist?" "Have you seen Hirak Rajar Deshe (The Kingdom of Diamonds)? There is a scene of the great clean-up where all the poor people are driven away. That is a direct reflection of what "I think that Pather Panchali is fairly ruthless in its depiction of poverty. The behavior of characters, the way that the mother behaves towards the old woman, is absolutely cruel. I don't think anyone has shown such cruelty to old people within a family. Distant Thunder takes place in a very pretty setting and this is a point that Kael makes, that Babita is a baby doll or something. She doesn't know that some Brahmin wives in the villages were very beautiful" [15].

\section{Analysis}

Remember the words of Nargheese Dutt who said the Sathyajith Ray's films mostly try to export India's poverty to the other nations! The movie Patherpanchali portrays the same situation of village life. In the canns film festival Patherpanchali was apprised as the best human document. The humanisation of the village life is been emphasised the movie. In this movie we could not find the conflicts between the social circumstances and the values of humanity. If examine the peripheral meaning this movie we could that India's village poverty is not only highlighted. In this movie was picturised in pr-independence era but in reality this movie has been shooted after the independence during 1950s; during this time the planning and development policies were highly discussed during the picturisation of this movie the interest of Nehru towards socialism five year plans the conference of INC etc. and all these issues were in the prevalence during the production of this film these was a situation where the movie maker had to plead in front of the Bengal government due to the inefficient fund to complete this movie. Even there was a situation to stop the production work of this film due to the economic crisis. Thereafter with the help of Bengal government this movie was able to finish the production. This movie does not favour the development policies of the government of that year. The movie maker Sathyajith Ray strong political ideologies were the reason far not supporting the development policies of ruling government during that government. Therefore the movie Patherpanchali were critically criticised alite class of those days. Now let us take the case of Appu's trilogy if we examine this movie compared to the 1st one we could find the growth of Appu was parallally related to the growth of the Country. In this movie Appu the social circumstances and ideologies of the ruling Mgovernment of those days are not shown directly. The critical viewers of this movies the art and technicalities were more studied. That is the reason Sathyajith Ray was not considered as the 
political film maker. If we politically evaluate Appus trilogy we also need to evaluate and analysis the development approaches of the ruling government of those days. There was a clear sense for the authorities on how to improve the growth of development in the country. But in Appu's trilogy unstability of the country has been picturised. The movie of Ray's was picturised completely against the development policies of the then government. The governmental policies of developing and governing the state was not the correct way how it should implement so the movie Appu trilogy showed, what kind of development India needed to the then government. The Ray's take off or the Ray's stand on the then government policies were shown in the work of Appu trilogy was favouring socialist ideology where everybody is seen within equal respect without discrimination of cast, colour, creed etc.

The movie of Ray's was picturised completely against the development policies of the then government. The governmental policies of developing and governing the state was not the correct way how it should implement so the movie Appu trilogy showed, what kind of development India needed to the then government. The Ray's take off or the Ray's stand on the then government policies were shown in the work of Appu trilogy was favouring socialist ideology where everybody is seen within equal respect without discrimination of cast, colour, creed etc. In the movie Sathyajith Ray more than socialist ideology a capitalist ideology is more emphasised and can be seen for examine the 'Gramin' (Rural) culture or upper class was more visualised. In the movie Sathyajith Ray apart from the development concepts of socialism was moving against the direction of socialist ideology. In the movie Patherpanchali the gandhiyan ideology of sarvodhaya has purely been emphasised the words of this movie also reminding the words of Swami viveganandhan that do not forget the illiterate village people as they are the result of modernised society. The movie Patherpanchali represents a political ideology of that era.

In India the rise of Marxist ideology and the recognisation Dalit artists have been idirectly represented in this movie. After the independence of the country even in India ther was a high and low class discrimination which prevailed in the country was showed in the movie. In the movie Patherpanchali the family of Harihar is shifting from village to the city is been picturised. But in Aparajitha the avoidance showed by Appu towards his mother has been criticised. The Bengali society and Bengali culture were not able to tolerate such picturisation in the movie. This is the reason for which I have. During the screening of the first show of Patherpanchali there were not much audience or the theatres many a times completely empty this statement was written in the autobiography of Bijoya Roy. The Bengali audience have viewed the movie of Ray as a common narrative on the series following series of Appu trilogy. The hidden voice of politics in that movie was unseen or unrecognised by the then audienceof Bengal state. The need for higher studies was the common needs of the youngsters. This notion was highly emphasised in the Appu's character though the movie Aparajitha. Therefore the value of modernisation was a desire and the reality of the parent system was questioned by Appu.

The mother's desire for Appu being traditionally a "purohit" and Appu who won't to go Culcuta for his angellican studies. Survaja's lonely, independent, sorrowful death was shown in this movie Sathyajith Ray has tried to picturise that even the life of a common women or a lady in Bengal is the same. When the traditional values gets challenged the new values undertakes the traditional values and they set platform for them during those situation these type of hardships gets situationalised. The problems of youngsters mainly unemployment hampers the creativity in them this situations are clearly pasteurised Apoorsansar. Appu's discomfort with the traditional values and his thirst for acquiring the angelican studies itself has been appreciatiated part of this movie. During the financial hardship Appu's wife in apoorsensar Aparna for jobs this represents a notion of gender equality where at the same time during the days women were not sent out of home for any jobs. Aparna prefixed marriage system and her death during the pregnancy represents a political situation of women during those days. The story was written by Vibhoothibhooshan before independence and after independence this book was turn into a movie which was a main reason to show the conditions and situations of two eras that before the independence and after independence.

In the villages of India the care given to health is not so effective. I this movie the creativity of youngsters have been highly hampered by the unethical situations and cruelty picturised through the movie.

Charulatha is the movie which Ray himself considers as best movie ever he had made. According to Ray if he remakes the movie he would picturised the movie in the same way and he personally feels this was the movie in which he made of a story by Tagore which was originally named 'the broken nest' The movie is known as amovie by the audience. With a good blessed and a very talented actor Madhavi Mukhargee had played the character of charulatha which brought a popularity for the movie itself. Western education renaissance and traditional beliefs where seen face to face during the picturisation of this movie. This was a change from badhraloge womens to a modernised society. Charulatha is the wife of Bhoopathi who was western educated, independent minded and a political believer. The character of bhoopathy is fighter for rights of Indian people who owns a newspaper organisation. The lonliness in the life of Charulatha has been picturised in the movie, and the movie start with picturising that The facial expressions and mannerisms shown through charulatha in the movie itself represents the feel being lonely are to the audiences. Charulatha looking through binocular to the outside world is picturised in this movie, this situation originally reveals the heart of women who wants to get out of her house and experience the real world outside her home. In another scene where Bhoopathy is going to the study hall he took a book and moving back to his office. In this situation he does not notice his wife Charulatha who is standing in front of him. All the actions of Bhoopathi do not notice Charulatha as he is highly involved in reading book. In the lonely life of Charulatha here comes a drastic change when Bhoopathi's niece named Amal comes in the life of Charulatha. The most celebrated eminent film director Satyajith Ray has picturised the political history of 70's and 80's through his film. It looks different and gets more popularity. According to him, politics the word itself is not a word - a word which is uses for violence and protest or we can say politics is the internal evolution of human beings who are suppressed by the society or by his surroundings. Rays character, Charulatha who played an important character in the film titled Charulatha. It is the brilliant political lesson. In the film Charulatha we can see conflict between virtues and wise, and also the conflict between traditional and modern values. Her family compared with a small birds nest. According to Satyajith Ray family is the most sacred institution in the world and we can see presence of the world of imperialism through the film. Comparatively the film Charulatha directed by Ray and novel charulatha written by Rabindranath Tagore has some similarities. And there never ends internal conflicts and compromise in those two literary forms. Women try to make a position in the society and try to proclaim as they are also strongest gender as compared to men. They wanted to fly the widest sky of freedom.

Charulatha written by Tagore picturised male dominated 
values which is the base for every family and instead of these things charulatha's story itself is the autobiography of Tagore and it deals with soul relationship between Tagore and his sister-in-law. According to Tagore his sister-in-law Kadambari not just a sister in law. They have a very emotional attachment with each other. She has a vital presence. His life she was the soul mate of his reading and writing. But they lost their relationship when Tagor gets married. Then Kadambari gets suicide. Tagore convey his feelings to these incidents. He says the suicide was most worseful moment in his life and universe become empty. We can say that the two Charulathas connected vice- versa. Mahanagar film deals with the life of women in Bengal who become earning from household slaves. We can see the same values here the story of the Subhrato and Arathi. A striking sentence erupted here. Women always existence should be as like a home maker "women's place is in the home". In the film the protagonist Arathi ran away from the superstitions of traditional values. And make her life as batter field. She compelled to go for job for her livelihood. Her family suppressed between traditional values and circumstances. Since she was lived in a four walled house which based on traditional values.

But later she has to face many difficulties thought her life she have walked alone the street and make contact with strange people. She compels to change her physical appearance as part her job. She feels freedom from her identity as home maker she was very sincere and loyal towards her job. So she gets many appreciations from her Bose but her husband Subratho irritated with the approach towards other gents its leads to the conflict on his mind. But he lost his job she compels to continue her job. The end of the film is full of problems her working place and home. Subrato stand like shade for her he pride about her views of justice and social commitments they continued thee life with new phases. At the film we compromise towards tradition. The tradition placed many superstations beliefs but the modern values also give birth to some injustice. The reasons for the failure of modernism is because of go back towards tradition. The women participation in all fields lead to many problems they can bring their own emotions in the all fields. They are stance for uniformity instead of male dominance. These two characters Arati and Charulatha are used as metaphor for strength and power.

In the film "Mahanagar" the does not have any wide presence most films of Ray released in 70's. The Ray's film shows the horrible face of the Calcutta in 70's. Unemployment, capitalism, developmend policies are mojor subjects of his films. City was not the primary presence in the film Mahanagar by satyajit ray. Through this film we can see only the image of office worked by Arathi and Subhrato and the view of city from there. The urban oriented film of Ray launched during 90's. For those film he selected the straggle of urban life of 70's Calcutta. That period urban life was haunted by the unemployment and illiteracy.

For the films Jana Aaranya, Simabaddha, Prathidwani known as Culcutta trilogy, Ray selected the background of distraction of development of skill by the introduction of morals and values. The film Pradidwani was biased on 70's youth. It was the period of the emergence of Nacsalate movement. Sidhsarth the protagonist in this film is the representative of the struggle and disappointment. He was the perfect hero with dedication and political perspective of ideal youngsters. In the opening scene we can see Sidharth attending an interview. There he answered the questions of interview board. He cunningly answered to the first question "does 1 like flowers". The second question was that "what was the important incident happened in previous decades"? He answered that was Vietnam War. His answer is stuffed with his own political perspective. Next question "did that occurs more importance than moon...." for this he answered that it was the development of technologies. But Vietnam War was the great protest of common people. After listening his answer Olathe interviewer asked a question that "Are you a communist". Finally he said that there is no need of to be a communist to respect Vietnam people towards the war. We can see the emergence of the political violence and nonviolence. Like extremists and non-extremists. They used violence and non-violence for the goodness of society. We can compared as it to a coin it have two side political violence and non-violence balanced their participation in society.

\section{Conclusion}

The politics in the films of Satyajith Ray has not been much examined. There are many legends of Indian film making, Satyajith has yet not being recoganised as a political film maker. Comparing with the film of Rithwik Ghatak and Mrinal Sen which are politically highly influential, Sathyajith Ray himself claims he is never a political film maker. But when we closely examine his films, we could read out a close relationship with Indian politics in his films. Satyajit Ray films suggested that the nature of elite class which developed by the the colonialism and imperialism was capable to include the evils of feudal system and capitalism. It promotes- to the balancing power of the impact if imperialism.

The film Jana Aranya shows a bundles of charactes who were fought and filed to the realities of their life. Satyajit Ray' films are highly political that deals with the all the levels of society. And also pictures the pathetic situation in our society. In India the rise of Marxist ideology and the recognisation Dalit artists have been indirectly represented and after the independence of the country even in India there was a high and low class discrimination which prevailed in the country was showed in the Appu Trilogy. We can also see the conflict between tradition and morden values in Satyajit Ray's films this is also the current political phenomenal in Indian society. Vietnam war, partion, capitalism, Indian socialism Gandhian development, are discussed in his films. That all are the pillars of Indian politics.

\section{References}

1. Deb Banerjee (2011) Powerful and powerless: power relations in Satyajith Ray Films. Cloud publications, Jadavpur.

2. William AR (2011) American political films 1968-1980. LAP Lambert Academic Publishing.

3. Aswin S, Mooney C (2011) Seven movies that changed the people political views.

4. Georakas Dan (2012) Cineaste Magazine.

5. Lavanya M Swati (2015) Pachakuthira Magazine, DC Books.

6. Varkey KT (2013) Introduction to political science. IJSS 7: 201-206.

7. Umesh K (2014) Bangla film through past. Madhyamam 8: 38.

8. Moinak B (2014) Political cinema. Economic and political Weekly 3: 17-19.

9. Unnikrishnan P (2013) Satyajit Ray jeevitham. Cinema, Sambhashanam.

10. Manas G (2009) Satyajit Ray retrieved from politics and resistence. EMIRJ 2 38-41.

11. Nikildas (2012) Politics and policies of Indian cinema. CURJ 7: 36-39.

12. Caroline H, Cahill M (2009) The beast of political culture and analysis of politica effects of self- objectification. IJRAS 5: 52-58.

13. Gibbs MH (2012) Film and political culture in post war Japan. Peter Laung Publishing group.

14. Moorgue (2011) Colonial discourses in Italian cinema. Inquirer 9: 12-18.

15. Vijth K (2013) Cinema and colonial India. Prabhav Publications. 